\title{
The Economic Cost of Secessionist Conflict in the Philippines
}

\section{Max Planck Institute for Tax Law and Public Finance}

Working Paper 2015 - 05

June 2015

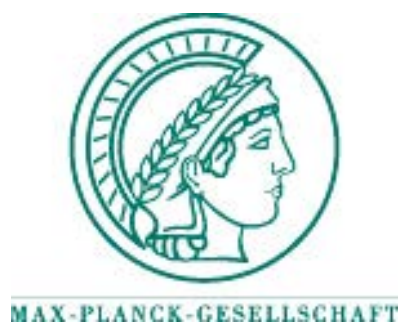

Max Planck Institute for

Tax Law and Public Finance

Department of Business and Tax Law

Department of Public Economics

http:/ /www.tax.mpg.de 
Working papers of the Max Planck Institute for Tax Law and Public Finance Research Paper Series serve to disseminate the research results of work in progress prior to publication to encourage the exchange of ideas and academic debate. Inclusion of a paper in the Research Paper Series does not constitute publication and should not limit publication in any other venue. The preprints published by the Max Planck Institute for Tax Law and Public Finance represent the views of the respective author(s) and not of the Institute as a whole. Copyright remains with the author(s).

Max Planck Institute for Tax Law and Public Finance

Marstallplatz 1

D-80539 Munich

Tel: $\quad+498924246-0$

Fax: $\quad+498924246-501$

E-mail: ssrn@tax.mpg.de

http://www.tax.mpg.de 


\title{
The Economic Cost of Secessionist Conflict in the Philippines
}

\author{
Rhea Molato*
}

May 8, 2015

\begin{abstract}
This paper estimates the effect of secessionist conflict in the Philippines on the country's economic output. It uses the synthetic control method (SCM) to generate the counterfactual path of per capita real GDP that the Philippines could have achieved in the absence of secessionist conflict. The effect is measured as the difference between actual and synthetic levels of economic output. This paper finds a negative and growing effect of the conflict on the Philippine economy as the conflict persists through time. These estimates are validated by the standard method of inference for studies using the SCM.
\end{abstract}

Keywords: secession, conflict, economic development

JEL Classification Codes: H77, N40, O10

* Max Planck Institute for Tax Law and Public Finance. Marstallplatz 1, Munich, Germany 80539. Correspondence: rhea.molato@gmail.com. I thank Kai A. Konrad, Nadja Dwenger, Erik Hornung and Davide Cantoni for helpful comments and suggestions. 


\section{Introduction}

The direct and immediate consequence of armed conflict manifests itself in the loss of lives, injuries, damage to property, disruption of normal affairs, and threat to security. Such effects are observable when a struggle for secession turns into a violent conflict. However, the effect of such a conflict on national income is not directly observable even if the country's income before and during the conflict can be observed. This is because the effect must be measured as the difference between actual income during the conflict and counterfactual income of the country if the conflict did not take place. The counterfactual levels of income during the period of secessionist conflict are not reported in national accounts. This paper uses the synthetic control method to estimate these counterfactual levels and measure the economic cost of secessionist conflict in the Philippines.

This paper finds that the counterfactual income of the Philippines can be measured as a convex combination of the income levels of four developing countries: Thailand, the Dominican Republic, Fiji and Zambia. This convex combination comprises a synthetic Philippines against which the Philippines' actual income levels can be compared. As the synthetic Philippines is not exposed to secessionist conflict, the effect of such a conflict on the Philippines' national income can be measured as the difference between the Philippines' actual income during the conflict period and the counterfactual income of the synthetic Philippines during the same time period.

Estimates show that the Philippines' actual income began to diverge from its counterfactual path as soon as the secessionist conflict began. Economic output of the country remained lower than the estimated income of the synthetic Philippines throughout the conflict period. This study estimates an economic cost averaging 400 US $\$$ per capita per year for the first 10 years of the secessionist conflict. This is equivalent to $18 \%$ of the country's average real GDP per capita per year during the same period. As the conflict persisted through another 10 years, the average cost amounted to more than 800 US\$ per capita per year, equivalent to $32 \%$ of the Philippines' average annual income during this 10-year 
period. By the third decade of the conflict, the average cost reached 1,600 US\$ per capita per year. This economic opportunity cost is equivalent to $46 \%$ of the country's average annual income per capita.

This study reveals a substantial economic cost of the secessionist conflict on the Philippines. Previous studies have focused on the direct costs of the conflict incurred during battle operations. For example, Buendia (2005) accounted that during the height of the civil conflict in the year 2000, approximately 10 million US\$ worth of property and infrastructure were destroyed. He reported that at this time the Philippine army spent 1-2 million US\$ a day for military operations on the war. However, studies on the total effect of the conflict on national income remain scarce due to measurement issues and difficulties in imputing values.

Schiavo-Campo and Judd (2005) estimated the "direct" annual economic cost of the conflict, which they define as output loss compared with the preconflict equilibrium, as $0.5 \%$ of the Philippines' GDP during the period 19751982. This was a period of high intensity in the armed conflict, and this was halfway along the first and second decades of the struggle. Their cost estimates for this period is roughly similar to their estimated economic cost for the end of the third decade. Throughout the whole period between 1970 and 2001, they impute the value of total direct output losses from the secessionist conflict to be around 2-3 billion US\$. In addition, they include foregone investments in their estimates of "indirect" economic costs between 1975-2002 which they project to be more than 10 billion US\$. To arrive at these estimates, they employed a cross-section regression analysis. These authors acknowledge that their method of assigning values on output losses was subject to imperfect data on prices of goods and they had to rely on partial indicators of some outputs. I abstract from such limitations by using data on national income normalized in constant terms and adjusted for purchasing-power parity (PPP).

To my knowledge, this is the first study applying the synthetic control method to estimate the economic cost of secessionist conflict in the Philippines. By constructing a synthetic control group similar to the Philippines in many respects except for the presence of secessionist conflict, this study is able to track 
the consequence of this conflict on the Philippines. Other studies measuring the economic cost of conflict used regression analyses on other countries exposed to civil war (Collier 1999; Murdoch and Sandler 2002; Llussá and Tavares 2011). These quantitative studies used a cross section of countries to test the effect of conflict on those countries engaged in domestic warfare. They find significant negative correlations between conflict and the steady state levels of GDP per capita as well as private consumption and investment.

The empirical method I use in this paper differs from previous studies on the cost of conflict in the Philippines and on the cost of civil conflict in general. The synthetic control method generates a causal effect as established in Abadie et al. (2010). By generating counterfactual levels of income in the absence of conflict, the effects estimated using the synthetic control method can be interpreted as a a result of the secessionist conflict itself.

The rest of the paper is organized as follows. Section 2 gives a historical account of the secessionist conflict taking place in the Philippines. The empirical method for estimating the cost of this conflict is explained in Section 3. It is followed in Section 4 by a description of the data and selection of the sample used in this study. The results containing the estimated effects of the conflict are shown in Section 5. It also includes the results of a test which verifies the estimates. Section 6 gives a brief conclusion. The Appendix contains a list of data sources.

\section{Historical background of the secessionist con- flict in the Philippines}

The Philippine history is characterized with two lines of development that progressed in parallel. One is the outcome of Spanish and American rule for nearly four centuries that took place in majority of the country's present territory. The other line is governed by Muslim settlers with 500 years of political, economic and cultural history concentrated in the southern area called Mindanao (Bara 
2011). For the most part of the western colonial period, these two lines of historical development remained largely disjoint. They involved different forms of government and ways of life following Christian and Muslim principles, respectively. In 1946, when the Philippines obtained freedom from foreign occupation, Mindanao was annexed as an official part of this independent nation.

In the 1950s, then President Ramon Magsaysay enforced a resettlement policy encouraging some Christians from the northern and central parts of the Philippines to move and build their livelihood in the southern island of Mindanao that is richly endowed with natural resources. This was an attempt at full integration of the country. However, this influx of immigrants resulted to unrest among the Muslim population who had originally settled in the area.

An incident known as the "Jabidah Massacre" in 1968 triggered insurgency among Muslims in Mindanao. At least 28 Moros recruited by the Philippine army were killed by army personnel during a training exercise. Outrage over this incident led to the formation of the Moro National Liberation Front (MNLF) in 1969, whose objective was to claim an independent state grounded on Islamic faith. The MNLF launched an organized Moro counter-offensive leading to armed conflict with the Philippine military. This resulted in casualties among the military, the separatists and civilian personnel.

Attempts at resolving the conflict involved several rounds of negotiations. In 1976, the MNLF and the Philippine government signed the Tripoli Agreement, which provides for autonomy in the Muslim-dominated areas of Mindanao. In March 1977, President Ferdinand Marcos declared autonomy in 13 provinces in Mindanao. Because the Philippine Constitution requires conducting a plebiscite before completely granting this autonomy, residents in these 13 provinces underwent a voting stage in April 1977. The MNLF objected to the idea of conducting this plebiscite. In the end, only 10 provinces voted for autonomy so Marcos implemented autonomy on these 10 provinces instead of the full set of 13 provinces.

The MNLF was not satisfied with the implementation of the Tripoli Agreement so it reverted to its original claim of fighting for independent statehood for 
Muslim Mindanao. In 1984, a faction of the MNLF was formally established as the Moro Islamic Liberation Front (MILF). It engaged in more violent activities in its fight for secession.

In 1986, the Philippine government drafted a new Constitution that included provisions for autonomy in Muslim Mindanao. This Constitution was ratified in 1987 while the MNLF and MILF objected to those provisions regarding autonomy.

In 1989, President Corazon Aquino signed into law a republic act that establishes the Autonomous Region in Muslim Mindanao (ARMM). In order to determine which provinces to include in this autonomous region, a plebiscite followed while the MNLF and MILF objected to this voting stage. With this plebiscite, only four provinces - Lanao del Sur, Maguindanao, Sulu and TawiTawi - opted for autonomy. These four provinces are marked light gray in the map of Mindanao illustrated in Figure 1, representing the ARMM established in 1989 .

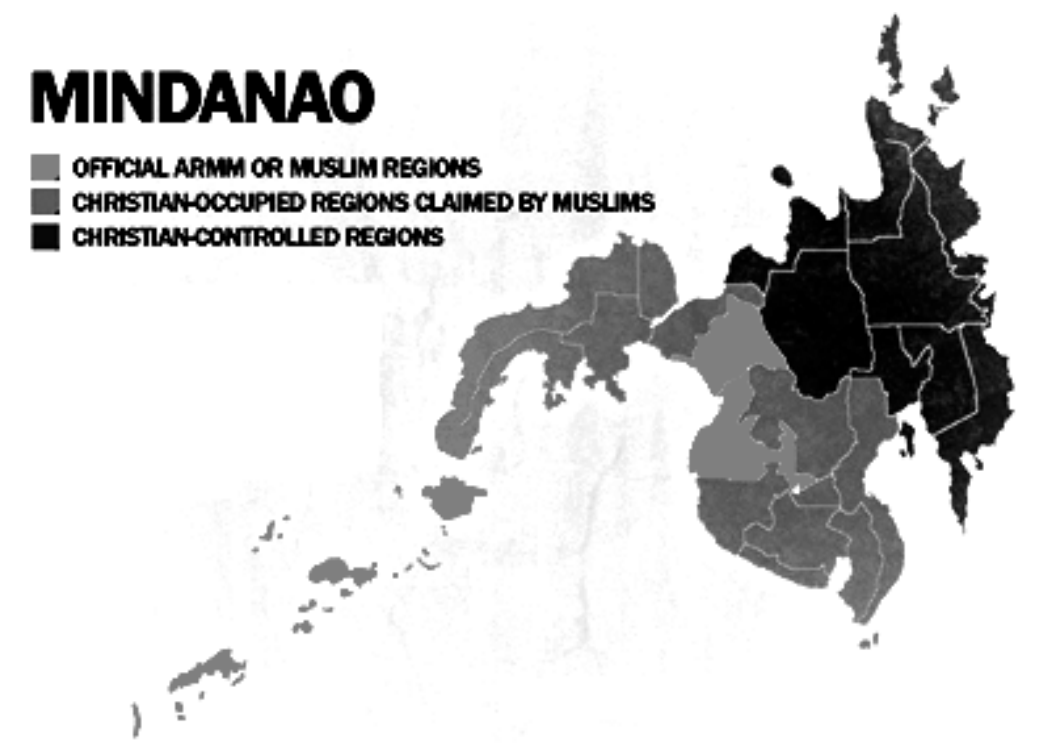

Figure 1. Map of Mindanao

The secessionists continue to claim other parts of Mindanao which are in- 
habited by a mix of Muslim descendants and Christian resettlers. The areas marked dark gray in Figure 1 represent the provinces under contention in this separatist conflict. To date, this threat of secession remains unresolved.

\section{The synthetic control method for estimating the cost of secessionist conflict}

To empirically estimate the effect of secessionist conflict on the Philippines, one needs to compare the actual economic output of the country during the conflict period with the output it would have achieved if the conflict had not occurred. While the Philippines' income in the presence of this secessionist conflict is observable, its income in the absence of the conflict is not. For this reason, one needs to generate a counterfactual trajectory of the Philippines' income without the secessionist conflict. In order to generate such a counterfactual, I create a synthetic control group using the synthetic control method (SCM) developed by Abadie and Gardeazabal (2003) and formally motivated by Abadie, Diamond and Hainmueller (2010).

The effect of secessionist conflict, $\theta_{t}$, is given by the difference between the Philippines' per capita income in the presence of secessionist conflict, $y_{t}$, and its income per capita if the conflict did not exist during the same time period, $y_{t}^{N}$ :

$$
\theta_{t}=y_{t}-y_{t}^{N} .
$$

This effect can be estimated by SCM as

$$
\widehat{\theta}_{t}=y_{t}-\sum_{j=1}^{J} w_{j}^{*} y_{j t}
$$

where $w_{j}^{*}$ refers to the weight assigned to country $j$ in the synthetic control group and $y_{j t}$ is the income per capita of country $j$ at time $t$. Each country 
$j=1, \ldots, J$ in the synthetic control group must be unexposed to secessionist conflict throughout the sample period for this country to qualify as a proper control unit.

The value of $w_{j}^{*}$ must be selected such that the resulting synthetic control group associated with $w_{j}^{*}$ closely reproduces the income levels of the Philippines prior to the secessionist conflict as well as the determinants of the Philippines' economic output. The pre-conflict levels of output determinants in the Philippines can be summarized in a vector $\mathbf{X}_{1}$ while the corresponding levels of output determinants in the synthetic control group can be summarized in a vector $\mathbf{X}_{0}$, each vector containing $q$ variables. The vector of weights $\mathbf{W}^{*}=\left(w_{1}^{*}, \ldots, w_{J}^{*}\right)^{\prime}$ can be optimally chosen as the value of $\mathbf{W}$ that minimizes:

$$
\sum_{m=1}^{q} v_{m}\left(\mathbf{X}_{1 m}-\mathbf{X}_{0 m} W\right)^{2}
$$

where $v_{m}$ is a weight assigned to variable $m$, reflecting the relative importance of this output determinant when matching the pre-conflict income levels of the Philippines with the income levels of the synthetic Philippines prior to the conflict period. The value of $v_{m}$ can be selected such that the resulting synthetic control group approximates the trajectory of the Philippines' income per capita before the secessionist conflict began.

One prospective challenge on the accuracy of the SCM estimator $\widehat{\theta}_{t}$ concerns the potential confounding effects of observed and unobserved factors on income. However, if the number of pre-conflict periods is sufficiently large, then matching on pre-conflict income helps control for these potential confounding factors (Abadie et al. 2011). If the Philippines and the synthetic control group exhibit similar income levels over a long period of time prior to the secessionist conflict, then any discrepancy in income during the conflict period can be interpreted as being caused by the conflict itself. 


\section{Data and sample}

This paper uses country-level panel data for the Philippines and other developing countries for the period 1960-2003. The secessionist movement in Mindanao was founded in 1969 which marks the beginning of the struggle for independence from the Philippines. As the conflict period starts in 1969, this data set includes 9 years of pre-conflict data. The sample period begins in 1960 because it is the first year for which data on real per capita GDP and economic growth predictors are available for countries in the potential control group. It ends in 2003 because one country in the potential control group (Thailand) became exposed to secessionist conflict within its territory after 2003, making it ineligible as a control unit for the years thereafer. All in all, this data set contains more than three decades of conflict period, sufficient to estimate both immediate and long-run effects of secessionist conflict on economic output.

Here I give a rationale for using country-level data. While a more disaggregate level of data may seem to more precisely estimate the effect of conflict in the area where it has been concentrated, this paper uses country-level data because region-level data on economic output and growth predictors are unavailable for the entire pre-conflict period. Moreover, the subject of the secessionist conflict

is not confined within one region. Proponents of secession claim independence for a set of provinces located in different regions. Actual incidents of terrorist attacks occurred in these provinces as well as in areas for which independence is not being claimed at all. For example, members of secessionist movements have waged terrorist attacks in major cities like Metro Manila, the country's capital. This suggests a strong potential externality of the conflict on non-secessionist areas of the country. Thus, using country-level data as the unit of analysis captures spillover effects on the rest of the country.

The outcome variable of interest is annual economic output at the country level, measured in this data set as PPP-adjusted GDP per capita normalized in terms of 2005 US dollar values. I took the data on output-based real GDP from the Penn World Table (version 8.0), which can be used to compare trends 
in productive capacity across countries and over time.

In the following paragraphs I explain the selection of countries into the potential control group. Because the synthetic Philippines is meant to reproduce the real per capita GDP that would have been observed for the counterfactual Philippines in the absence of secessionist conflict, the potential control group must exclude countries which have been exposed to secession-related conflict during the sample period. Data on the presence of secessionist movements come from the Armed Conflict Dataset (ACD) of the Peace Research Institute Oslo (PRIO).

The values of economic growth predictors for the Philippines comprise the elements in $\mathbf{X}_{1}$ while the corresponding values of these growth predictors for countries in the potential control group comprise the elements in $\mathbf{X}_{0}$. The set of economic growth predictors is chosen among the standard set of determinants in neoclassical growth models: the rate of investment flow, population density, the share of agriculture/industry/manufacturing/services in GDP, and the human capital index. The Appendix identifies the sources of data on these variables used in this study. These variables are averaged over the whole preconflict period (1960-1968). Due to data limitations, countries with no available information on a growth predictor for the whole pre-treatment period had to be dropped from the sample. The synthetic control method cannot be implemented if at least one country in the sample contains no data point for a variable because it requires an average for each growth predictor throughout the pre-conflict period.

To minimize interpolation bias, I restrict the potential control group to those countries with similar pre-conflict characteristics to those of the Philippines. I chose a subset of developing countries whose pre-conflict growth predictors lie within 20 places of the Philippines' worldwide rank in each of these variables. After applying the exclusion criteria described in this section, the following countries qualified for the potential synthetic control group: Botswana, Cameroon, the Dominican Republic, Fiji, Honduras, Malaysia, Thailand and Zambia.

Using the synthetic control method, I construct a synthetic Philippines that 
reproduces the values of economic growth predictors in the Philippines before the secessionist conflict began. I estimate the effect of secessionist conflict on economic output as the difference in real per capita GDP between the Philippines and its synthetic counterpart during the conflict period. I then perform a series of placebo studies to test whether my estimated effects for the Philippines are unusually large relative to the distribution of the estimates that I obtain when I apply the same procedure to other countries in the sample, where actual secessionist conflict did not take place.

\section{Results}

To evaluate the effect of secessionist conflict, this study shows how real per capita GDP would have evolved in the Philippines after 1969 in the absence of this conflict. The effects are estimated as follows.

\subsection{Estimates of the effect of secessionist conflict}

The synthetic Philippines is constructed as the convex combination of countries in the potential control group that most closely resembled the Philippines in terms of pre-conflict values of economic growth predictors. Table 1 presents the results of this matching, which compares the pre-conflict characteristics of the Philippines with those of the synthetic Philippines. The synthetic Philippines closely reproduces the values of per capita real GDP and most of the economic growth predictors in the Philippines prior to the secessionist conflict. The population density of the Philippines is an outlier ${ }^{1}$ among the population density values in all the other countries in the set, which explains why matching on this variable can hardly be achieved. Nevertheless, population density was assigned

\footnotetext{
${ }^{1}$ The average population density of the Philippines throughout the whole pre-conflict period is equal to 102 persons per square kilometer of land area. Among the 8 countries in the potential control group, the median population density among country averages prior to secessionist conflict in the Philippines is 23. The highest pre-conflict average is 80 (Dominican Republic), still way below the Philippine average.
} 
a low $v_{m}$ weight $(0.145)$ among the growth predictors so that this variable is less important in the matching process than investment flow rate $\left(v_{m}=0.282\right)$ and industry share $\left(v_{m}=0.201\right)$, for which Table 1 indicates a good fit. The rest of the growth predictors in the Philippines were nearly reproduced by the synthetic Philippines.

\begin{tabular}{|l|l|l|l|}
\hline Growth Predictor & $\begin{array}{l}\text { Actual } \\
\text { Philippines }\end{array}$ & $\begin{array}{l}\text { Synthetic } \\
\text { Philippines }\end{array}$ & $\begin{array}{l}\text { Standard } \\
\text { Error }\end{array}$ \\
\hline Investment flow rate & 0.043 & 0.042 & 0.001 \\
\hline Agriculture (\% of GDP) & 27.265 & 28.824 & 1.559 \\
\hline Industry (\% of GDP) & 31.228 & 24.008 & 7.221 \\
\hline Manufacturing (\% of GDP) & 24.336 & 15.359 & 8.977 \\
\hline Services (\% of GDP) & 41.507 & 47.169 & 5.662 \\
\hline Human capital index & 1.724 & 1.617 & 0.107 \\
\hline Population density & 102.102 & 62.238 & 39.864 \\
\hline
\end{tabular}

Table 1. Economic growth predictor means

Table 2 presents the weights of each country in the synthetic Philippines. The weights reported in Table 2 indicate that economic output in the Philippines prior to the secessionist conflict is best reproduced by a convex combination of the economic output levels of Thailand (0.562), the Dominican Republic (0.315), Fiji (0.102) and Zambia (0.201). The synthetic control estimation assigns zero $\mathbf{W}$-weights to the rest of the countries in the potential control group (note that SCM does not allow for negative weights in order to avoid extrapolation). The levels of economic output and output determinants in these countries during the years prior to the secessionist conflict are outside the convex hull of the Philippines' pre-conflict levels. Thus, these countries do not comprise the synthetic control group. 


\begin{tabular}{|c|c|}
\hline Country & Weight \\
\hline Botswana & 0 \\
\hline Cameroon & 0 \\
\hline Dominican Republic & 0.315 \\
\hline Fiji & 0.102 \\
\hline Honduras & 0 \\
\hline Malaysia & 0 \\
\hline Thailand & 0.562 \\
\hline Zambia & 0.021 \\
\hline
\end{tabular}

Table 2. Country weights in the synthetic control

Figure 2 displays per capita real GDP for the Philippines and its synthetic counterpart during the period 1960-2003. Per capita real GDP in the synthetic Philippines follows the trajectory of actual income per capita in the Philippines for the entire pre-conflict period. Combined with the high degree of balance on the economic growth predictors (Table 1), this suggests that the synthetic Philippines provides an approximation to the real GDP per capita that the Philippines would have achieved if there had been no active threat of secession. 


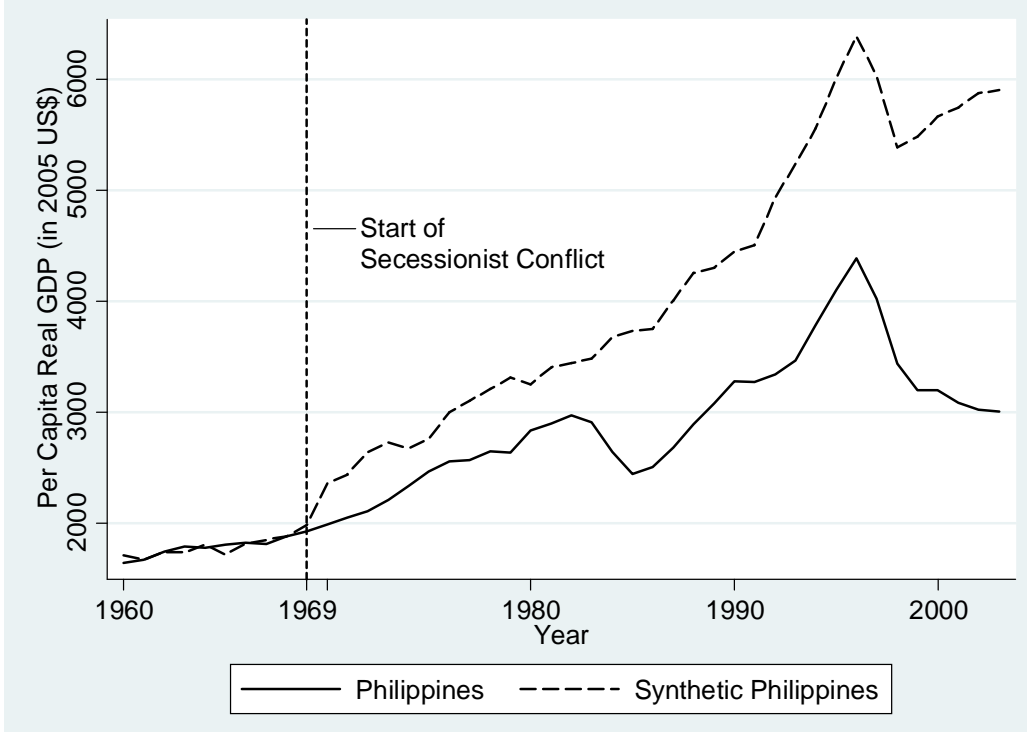

Figure 2. Trends in per capita real GDP: the Philippines vs.

synthetic Philippines

The effect of secessionist conflict on economic output in the Philippines is estimated as the difference between the levels of per capita real GDP in the Philippines and its synthetic counterpart during the period of conflict. Figure 2 indicates that the actual GDP path of the Philippines began to diverge from its synthetic counterpart as soon as the conflict started. The actual economic output is less than the synthetic output throughout the whole period of secessionist conflict. The gap is getting wider over time, indicating that the long-run effect on foregone economic output is growing as the conflict persists. The magnitude of this gap is reflected in the following figure. 


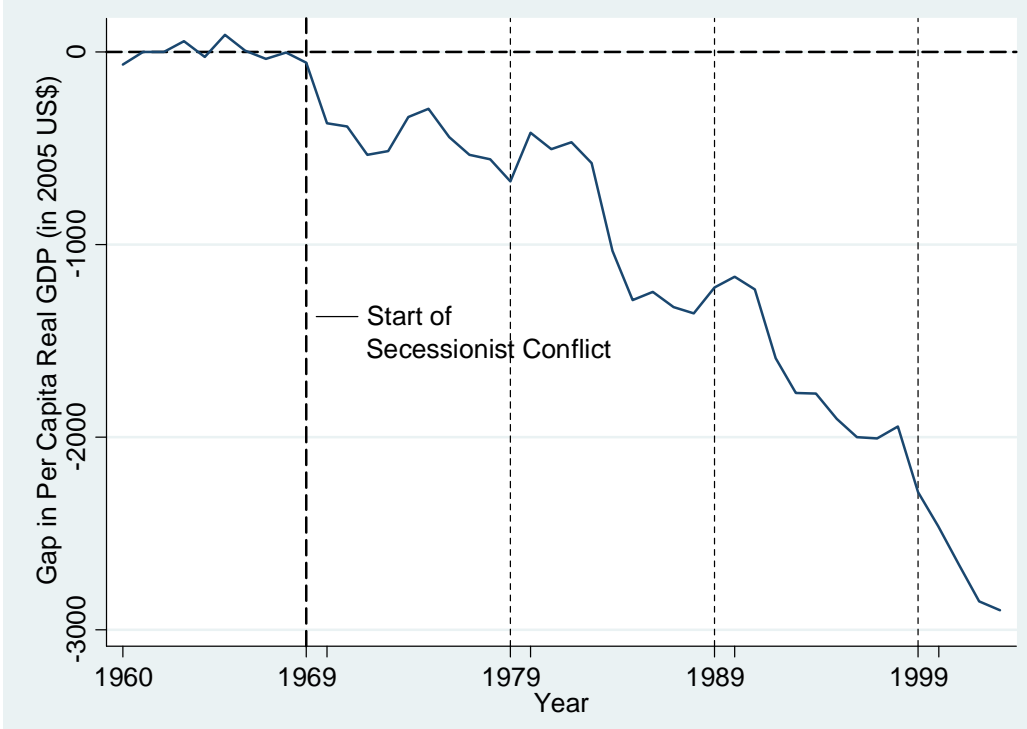

Figure 3. Per capita real GDP gap between the Philippines and synthetic Philippines

Figure 3 plots the yearly estimates of the effects of secessionist conflict, that is, the difference in per capita levels of real GDP between the Philippines and its synthetic version at every year since the conflict began. The economic cost is estimated at 400 US $\$$ per capita per year on average during the first 10 years of the conflict. This is equivalent to about $18 \%$ of the Philippines' average annual real GDP per capita during the same period. In other words, the average person in the Philippines would have earned $18 \%$ more than his actual income every year during this time if the armed conflict in southern Philippines did not occur.

As the conflict persisted through another 10 years, the foregone income per capita increased to an average of more than 800 US $\$$ per capita per year. This is equivalent to $32 \%$ of the Philippines' average annual income per capita during this 10-year period. By the third decade of the conflict, when it became even more intense, the economic opportunity cost reached a 10-year average of 1,600 US\$ per capita per year. This value is equivalent to $46 \%$ of the average annual 
per capita income throughout this time period.

This economic opportunity cost captures direct effects on the affected regions and negative externalities on the rest of the country. The negative externalities arise from the overall threat to security and bad international reputation (Worldwide Governance Indicators, World Bank). They include foregone investments, among others. The pattern captured in these estimates reflects the economic impact of missed opportunities and diverted investments which would have flowed into the Philippines if the secessionist conflict had not taken place. In particular, it shows that the Philippines failed to maximize potential benefits from the influx of foreign direct investments on Southeast Asia which began in the 1980s (Silliman 1984). This was a development in which Thailand fared better (Jitsuchon 2002), and since Thailand carries $56 \%$ of the weight in the synthetic Philippines, estimates of the Philippines's counterfactual income contains information on potential economic gains that the Philippines would have realized from higher inflows of foreign direct investments, among many others.

\subsection{Testing the validity of estimates}

To evaluate the validity of these estimates, I use placebo studies which test whether the estimated gaps are a result of the secessionist conflict itself or whether these gaps are merely a "placebo effect" from introducing some form of intervention. Similar to placebo tests in medical research, I conduct this test by assigning a placebo treatment to each country $j$ in the sample where no actual secessionist conflict occurred during the sample period. In each placebo run, I treat each country $j$ as if it were subject to conflict since 1969 (when the actual conflict started in the Philippines). Then I create a corresponding synthetic control group for each country $j$ using the synthetic control method. Every country $i \neq j$ in the sample receives a weight $w_{i}^{*} \geq 0$ in country $j$ 's synthetic control group.

After generating a synthetic control group for each country $j$, I estimate the counterfactual GDP level for its synthetic version as the weighted average of 
GDP per capita of the countries in $j$ 's synthetic control group:

$$
\sum_{\forall i \neq j} w_{i}^{*} y_{i t}
$$

where $y_{i t}$ is the level of GDP per capita in country $i$ at year $t$. This counterfactual GDP level can be matched against counry $j$ 's actual GDP per capita at year $t$, $y_{t}^{j}$, to generate a placebo gap for country $j$ at year $t$, equal to

$$
\widehat{\theta}_{t}^{j}=y_{t}^{j}-\sum_{\forall i \neq j} w_{i}^{*} y_{i t} .
$$

The placebo gap for each country $j$ can be compared with the GDP gap estimated in Section 5.1 for the actual treatment in the Philippines. If the placebo runs display gaps of magnitude and direction similar to the estimated GDP gap for the Philippines, then the estimated effect of secessionist conflict in the Philippines is considered a mere "placebo effect." The estimated gap cannot be interpreted as an effect of the conflict itself if a similar gap manifests in cases where actual conflict (treatment) did not take place. If, on the other hand, the placebo test reveals that the gap estimated for the Philippines is exceptionally large compared to the gaps estimated in the placebo runs, then the estimated effect in the Philippines can be ascribed to the secessionist conflict because such a gap turns up only in the specific case where actual conflict (treatment) occurred.

This inferential technique developed by Abadie et al. (2014) serves as an alternative to traditional statistical inference. Statistical inference is not well suited when the number of units in the control group is small, when there is no randomization in the assignment of treatment, and when sample units were not selected by probabilistic sampling. This is the case when measuring the effect of a historical intervention on one country. The alternative method of inference using placebo tests, on the other hand, does not require a large 
number of comparison units nor time periods and it can be used whether data are individual or aggregate.

Figure 4 displays the results of these placebo studies. Each line represents the gap estimated for each country in the placebo runs, more precisely, the difference in per capita real GDP between each country and its respective synthetic version, $\widehat{\theta}_{t}^{j}$ for every $j$. The superimposed thick line shows the gap previously estimated for the Philippines.

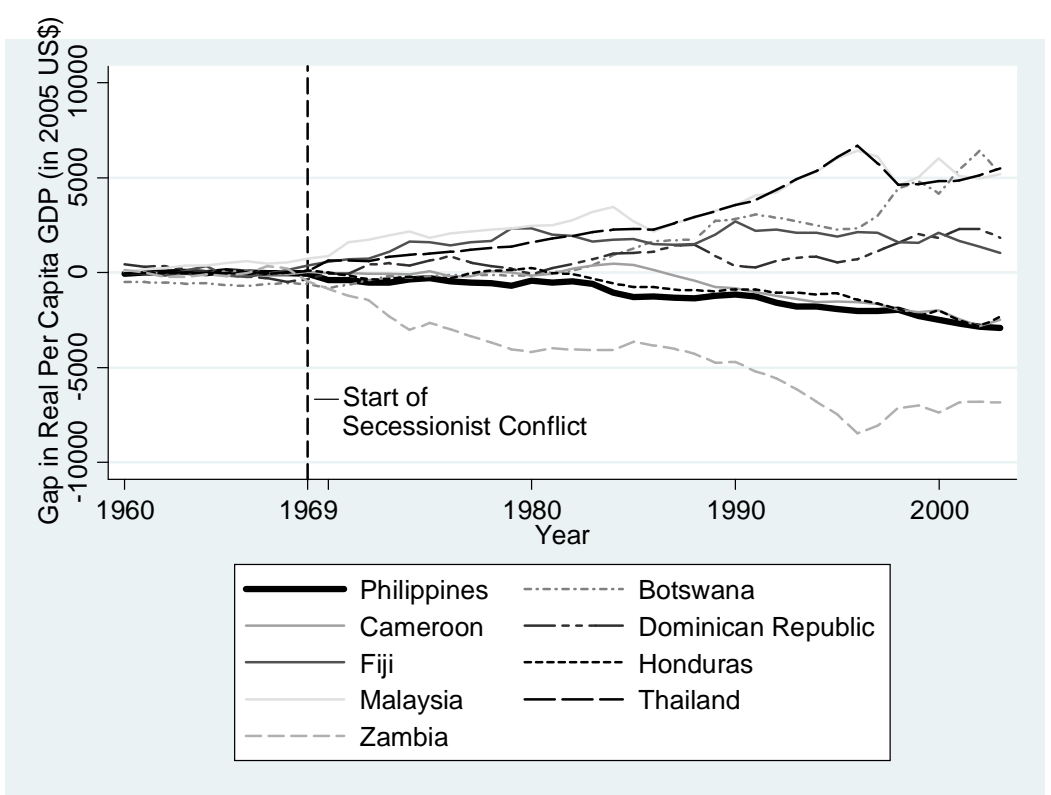

Figure 4. Per capita GDP gap in the Philippines and placebo gaps in sample countries

The effectiveness of each placebo run in testing the validity of synthetic control estimates is measured by the associated root mean squared prediction error (RMSPE) prior to the conflict. ${ }^{2}$ Essentially, the RMSPE measures lack of ${ }^{2}$ Pre-conflict RMSPE $=\sqrt{\frac{1}{T_{0}} \sum_{t=1}^{T_{0}}\left(y_{t}^{j}-\sum_{\forall i \neq j} w_{i}^{*} y_{i t}\right)^{2}}$, for all pre-conflict years $t=$
$1, \ldots, T_{0}$ in country $j$. 
fit between country $j$ and its synthetic control group during the period before the conflict began (Abadie et al. 2014). A low RMSPE indicates that the resulting synthetic control group closely mimics country $j$, thus, it can generate a proper counterfactual. On the other hand, a high RMSPE indicates poor fit between country $j$ and its synthetic counterpart so the resulting synthetic version of the country differs largely. To make transparent the goodness-of-fit in each placebo run in Figure 4, Table 3 presents the pre-intervention RMSPE for each synthetic country along with the pre-intervention RMSPE for the synthetic Philippines. It shows that some of the placebo runs provide a good fit while some placebo runs did not generate a well-fitted synthetic version.

\begin{tabular}{|c|c|}
\hline Synthetic Country & Pre-intervention RMSPE \\
\hline Philippines & 43.513 \\
\hline Botswana & 572.118 \\
\hline Cameroon & 60.408 \\
\hline Dominican Republic & 303.467 \\
\hline Fiji & 167.235 \\
\hline Honduras & 64.041 \\
\hline Malaysia & 419.167 \\
\hline Thailand & 25.898 \\
\hline Zambia & 191.067 \\
\hline
\end{tabular}

Table 3. Pre-intervention RMSPE of synthetic countries

Placebo runs with poor fit prior to the intervention cannot serve as a proper yardstick in testing the validity of a synthetic control estimate that demonstrates good fit. For this reason, I include in the inference test only the placebo runs with good fit, i.e., less than four times the pre-intervention RMSPE of the synthetic Philippines, and I exclude placebo runs which do not meet this threshold. 


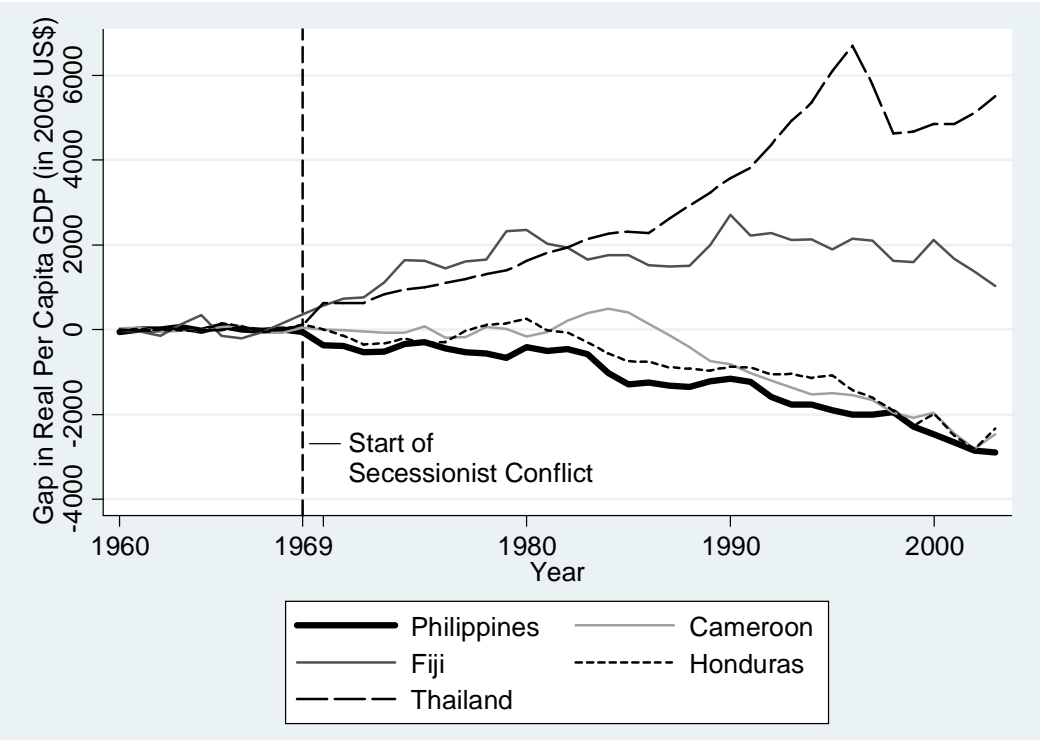

Figure 5. Per capita GDP gap in the Philippines and placebo gaps in countries with good fit

Figure 5 shows the final result of this placebo test. It evaluates the estimated GDP gap for the Philippines against the placebo gaps for countries with good fit in the placebo studies. It shows that the size of estimated gap for the Philippines is unparalleled by any of the estimated gaps in the falsification exercise. This test validates the estimated treatment effect for the Philippines as being caused by the secessionist conflict itself because the magnitude cannot be replicated in placebo treatments where actual conflict is non-existent.

As a final way to evaluate the Philippine GDP gap relative to the placebo gaps, I examine the distribution of ratios between post-conflict and pre-conflict RMSPEs. Post-conflict RMSPE measures how closely (or remotely) the synthetic country can mimic the actual country during the treatment period. A high post-conflict RMSPE indicates that the actual country deviates largely from its synthetic version during the conflict period, suggesting that the treatment has had a large effect during this period. In this final test, I normalize each 
country's post-conflict RMSPE to its respective pre-conflict RMSPE, generating an RMSPE ratio equal to

$$
\text { RMSPE ratio }=\frac{\text { Post-conflict RMSPE }}{\text { Pre-conflict RMSPE }},
$$

to allow for normalized comparison of GDP deviations among all countries in the sample. If the RMSPE ratio for the Philippines is larger than the RMSPE ratio for the other countries, this means that the normalized deviation of the Philippines during the treatment period cannot be replicated by placebo treatments.

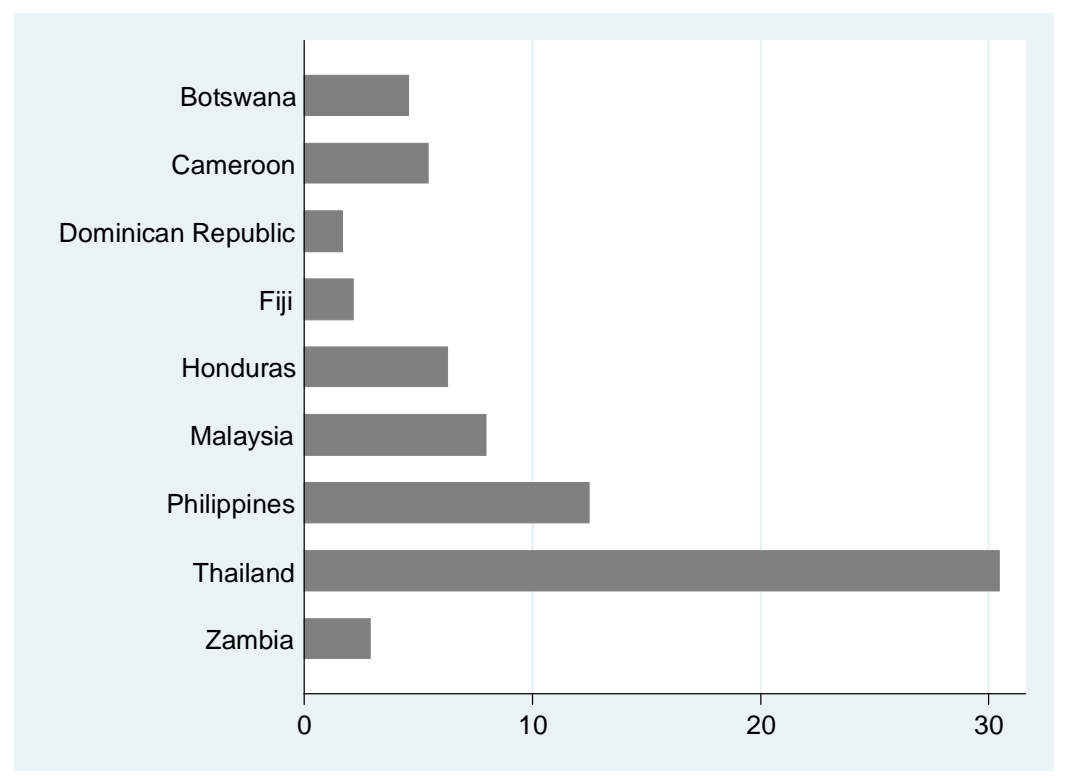

Figure 6. Ratio of post-conflict to pre-conflict RMSPE: the

Philippines and placebo countries

Figure 6 displays the distribution of post-conflict to pre-conflict RMSPE ratios for the Philippines and the other countries in the sample. While the ratio for Thailand stands out in this figure, the direction of the gap estimated for Thailand is opposite to that of the Philippines (see Figure 5). Thus, the Thailand placebo cannot invalidate the estimated effect of intervention for the Philippines. Now comparing the post-conflict to pre-conflict RMSPE ratio of 
the Philippines with the rest of the sample, no other country achieves a ratio as large as the Philippines'. This indicates that the magnitude in combination with the direction of the estimated treatment effect is unique to the Philippine case. Therefore, this test further strengthens the validity of synthetic control estimates in this chapter as the effect of secessionist conflict in the Philippines.

\section{Conclusion}

This study generates a synthetic Philippines as the convex combination of similar countries that are not exposed to secessionist conflict. This synthetic Philippines reveals the counterfactual levels of real per capita GDP that the Philippines would have achieved if it had not been exposed to an armed separatist conflict. The difference between the Philippines' actual income and the synthetic Philippines' counterfactual income represents the economic opportunity cost of the secessionist conflict in southern Philippines. The estimates illustrate that the annual costs are substantial and growing as the conflict persists through time. These estimates are validated by standard inference from placebo tests normally applied to synthetic control studies. 


\section{Appendix}

\section{Sources of Data for Economic Growth Predictors}

Investment Flow Ratio - from the Penn World Table (PWT) 8.0, measured as the rate of change in capital stock

Population Density - from the World Development Indicators of the World Bank, measured as the number of persons per square kilometer

Agriculture Share (\% of GDP) - from the World Development Indicators of the World Bank, measured as the percentage value added of the agriculture sector in GDP

Industry Share (\% of GDP) - from the World Development Indicators of the World Bank, measured as the percentage value added of the industry sector in GDP

Manufacturing Share (\% of GDP) - from the World Development Indicators of the World Bank, measured as the percentage value added of the manufacturing sector in GDP

Services Share (\% of GDP) - from the World Development Indicators of the World Bank, measured as the percentage value added of the services sector in GDP

Human Capital Index - from the Penn World Table (PWT) 8.0, based on years of schooling (Barro/Lee, 2010) and returns to years in education (Psacharopoulos, 1994) 


\section{References}

[1] Abadie, A., Diamond, A., \& Hainmueller, J. (2010). Synthetic control methods for comparative case studies: Estimating the effect of California's tobacco control program. Journal of the American Statistical Association, 105(490).

[2] Abadie, A., Diamond, A., \& Hainmueller, J. (2011). Synth: An R Package for Synthetic Control Methods in Comparative Case Studies.

[3] Abadie, A., Diamond, A., \& Hainmueller, J. (2014). Comparative politics and the synthetic control method. American Journal of Political Science.

[4] Abadie, A., \& Gardeazabal, J. (2003). The economic costs of conflict: A case study of the Basque Country. American economic review, 113-132.

[5] ARMM (2013). "ARMM History." Retrieved from the Official Website of the Autonomous Region in Muslim Mindanao http://armm.gov.ph/history/, 04 March 2014

[6] Asian Institute of Journalism and Communication (2011) "History of ARMM." Retrieved from http://www.muslimmindanao.ph/armm.html, 05 July 2013

[7] Bara, H. (2011). "The History of the Muslim in the Philippines." National Commission for Culture and the Arts, Retrieved from http://www.ncca.gov.ph/about-culture-and-arts/articles-on-c-na/article.php?i=232\&igm=4, 04 March 2014

[8] Buendia, R. G. (2005). The state-Moro armed conflict in the Philippines Unresolved national question or question of governance? Asian Journal of Political Science, 13(1), 109-138.

[9] Collier, P. (1999). On the economic consequences of civil war. Oxford economic papers, 51(1), 168-183. 
[10] Feenstra, R., Inklaar, R., \& Timmer, M. (2013). The Next Generation of the Penn World Table [Data file]. Groningen Growth and Development Centre. Retrieved from http://www.ggdc.net/pwt/.

[11] Gleditsch, N., Wallensteen, P., Eriksson, M., Sollenberg, M. \& Strand, H. (2002). "Armed Conflict 1946-2001: A New Dataset." Journal of Peace Research 39(5).

[12] GMA News Online (2014). "History of conflict: A timeline of the GPHMNLF peace process - OPAPP." GMA News Network, Retrieved from http://www.gmanetwork.com/news/story/326471/news/specialreports/historyof-conflict-a-timeline-of-the-gph-mnlf-peace-process-opapp, 03 March 2014

[13] Jitsuchon, S. (2002). Thailand's economic growth: a fifty-years perspective (1950-2000). Mimeograph, Thailand Development Research Institute.

[14] Llussá, F., \& Tavares, J. (2011). Which terror at which cost? On the economic consequences of terrorist attacks. Economics Letters, 110(1), 5255.

[15] Mankiw, N. G., Romer, D., \& Weil, D. N. (1992). A contribution to the empirics of economic growth. The Quarterly Journal of Economics, 107(2), 407-437.

[16] Murdoch, J. C., \& Sandler, T. (2002). Economic growth, civil wars, and spatial spillovers. Journal of Conflict Resolution, 46(1), 91-110.

[17] National Consortium for the Study of Terrorism and Responses to Terrorism (START). (2012). Global Terrorism Database [Data file]. Retrieved from http://www.start.umd.edu/gtd, 03 July 2013

[18] Schiavo-Campo, S., \& Judd, M. P. (2005). The Mindanao conflict in the Philippines: Roots, costs, and potential peace dividend (Vol. 24). Conflict Prevention \& Reconstruction, Environmentally and Socially Sustainable Development Network, World Bank. 
[19] Silliman, G. S. (1984). The Philippines in 1983: authoritarianism beleaguered. Asian Survey, 149-158.

[20] The Voice of the Martyrs (2009). "Octo-

ber $2009 \quad$ Newsletter Media" Retrieved from
http://www.persecution.com/public/media.aspx?mediapage_ID=MTgx, 04 July 2013

[21] World Bank (2013). World Development Indicators [Data file]. Retrieved from http://databank.worldbank.org/data/home.aspx 